\title{
Kualitas Pengaruh Pemberian Persentase Bawang Putih (Allium Sativum) terhadap Uji Organoleptik Sie Balu Daging Kerbau
}

\author{
(Percentage of Giving Effect of Garlic (Allium Sativum)on Organoleptic \\ Sie Balu Buffalo Meat)
}

\author{
Ardiansyah $^{1}$, Amhar Abu Bakar ${ }^{1}$ Cut Aida Fitri ${ }^{1}$ \\ ${ }^{1}$ Program Studi Peternakan, Fakultas Pertanian, Universitas Syiah Kuala
}

\begin{abstract}
Abstrak. Suatu penelitian telah dilakukan tentang Pengaruh Pemberian Persentase Bawang Putih (Allium sativum) Terhadap Uji Organoleptik Sie Balu Daging Kerbau. Penelitian ini dilaksanakan di Laboratorium Pengolahan Daging dan Ikan Jurusan Peternakan Fakultas Pertanian Universitas Syiah Kuala yang berlangsung dari Juni sampai dengan Juli 2016. Adapun tujuan penelitian ini adalah untuk mengamati pengaruh pemberian Persentase Bawang Putih (Allium sativum) Terhadap Uji Organoleptik Sie Balu Daging Kerbau. Penelitian ini menggunakan Rancangan Acak Lengkap (RAL) dengan 4 perlakuan dan 5 ulangan. Perlakuan P0 adalah pada pemberian $0 \%$ Bawang Putih (kontrol), perlakuan P1 adalah pada pemberian $10 \%$ Bawang Putih dari berat daging, perlakuan P2 adalah pada pemberian $15 \%$ Bawang Putih dari berat daging dan perlakuan P3 adalah pada pemberian $20 \%$ Bawang Putih. Parameter yang diamati dalam penelitian ini adalah uji organoleptik meliputi warna, aroma, rasa dan keempukan. Panelis yang digunakan adalah sebanyak 25 orang yang terdiri dari 10 orang ibu rumah tangga, 5 orang dosen, dan 10 orang mahasiswa Jurusan Peternakan Fakultas Pertanian Universitas Syiah Kuala. Hasil penelitian menunjukkan bahwa Sie Balu daging Kerbau dengan berbagai pemberian persentase bawang putih tidak berpengaruh nyata $(\mathrm{P}>0.05)$ terhadap uji warna, aroma, rasa dan keempukan.
\end{abstract}

Kata kunci : Bawang Putih, sie balu Daging Kerbau, Organoleptik.

Abstract. A study has been conducted on the Effect of Percentage of Garlic (Allium sativum) Organoleptic Test Against Sie Balu Buffalo Meat. This research was conducted at the Laboratory of Meat Processing and Fish Department of Animal Husbandry Faculty of Agriculture, University of Syiah Kuala which lasts from June to July 2016. The purpose of this study was to observe the effect of percentage of Garlic (Allium sativum) Organoleptic Test Against Sie Balu Buffalo Meat. This study uses a completely randomized design (CRD) with 4 treatments and 5 replications. Treatment $\mathrm{P} 0$ is the provision of $0 \%$ Garlic (control), treatment P1 is the provision of $10 \%$ of the weight of the meat Garlic, P2 treatment is the administration of $15 \%$ of the weight of the meat Garlic and treatment P3 is the administration of $20 \%$ Garlic. The parameters observed in this study is the organoleptic tests include color, aroma, flavor and tenderness. Panelists in use is of 25 people consisting of 10 housewives, five lecturers and 10 students of Department of Animal Husbandry Faculty of Agriculture, University of Syiah Kuala. The results showed that Balu Sie buffalo meat with various percentages administration of garlic not significant $(\mathrm{P}>0.05)$ to test the color, aroma, flavor and tenderness.

Keywords: Garlic, sie balu Buffalo Meat, Organoleptic.

\section{PENDAHULUAN}

Daging adalah bahan pangan yang bernilai gizi tinggi karena kaya akan protein, lemak, mineral serta zat lainnya yang sangat dibutuhkan tubuh. Usaha penyediaan daging memerlukan perhatian khusus karena daging mudah dan cepat tercemar oleh pertumbuhan mikroorganisme. Daging sangat baik bagi pertumbuhan dan perkembang biakkan mikroorganisme sehingga dapat menurunkan kualitas daging. Penurunan kualitas daging ditandai melalui perubahan warna, rasa, aroma bahkan pembusukan. Usaha untuk meningkatkan kualitas daging dilakukan melalui pengolahan atau pengawetan yang lebih baik sehingga dapat mengurangi kerusakan atau kebusukan selama penyimpanan.

Langkah-langkah yang dapat dilakukan untuk mempertahankan kualitas daging tersebut adalah melakukan penanganan seperti pengawetan dan pengeringan (Sie balu) (Soeparno, 2005). Sie balu merupakan produk daging yang paling mudah pembuatannya. Daging disayat 
tipis, kemudian dijemur atau dikeringkan dengan alat pengering. Daging kering mempunyai aroma yang agak berbeda dengan daging segar karena terjadinya oksidasi lemak sehingga menyebabkan daging kering mempunyai aroma yang khas.

Salah satu bahan pengawet alami yang baik digunakan dalam pembuatan sie balu adalah bawang putih. Bawang putih mempunyai senyawa allisin, zat-zat ini ampuh untuk membunuh mikroba. Allisin adalah senyawa yang secara efektif menghambat degradasi yaitu proses pemecahan protein menjadi molekul-molekul sederhana (seperti asam amino). Ekstrak rempah-rempah bawang putih memperlambat metabolism mikroba, pemanfaatan campuran bawang putih ini selain pada ikan sangat potensial untuk diterapkan untuk pengawetan daging (Widaningrum dan Winarti, 2005).

\section{METODE PENELITIAN}

Penelitian ini dilaksanakan di Laboratorium Pengolahan Daging dan Ikan Jurusan Peternakan Fakultas Pertanian Universitas Syiah Kuala Banda Aceh, dan Penelitian ini berlangsung selama dua bulan dari Juni sampai Juli 2016.

\section{MATERI DAN METODE}

\section{Daging}

Materi utama penelitian ini adalah daging kerbau sebanyak $4 \mathrm{~kg}$ yang dibeli di pasar daging Peunayong Banda Aceh, sedangkan bahan perlakuan adalah bawang putih sebanyak 2 ons dan pemberian garam 8 gram.

\section{Metode Penelitian}

Rancangan yang digunakan dalam penelitian ini adalah Rancangan Acak Lengkap (RAL) yang terdiri atas 4 perlakuan dengan 5 ulangan, sehingga terdapat 20 unit percobaan. yang susunan perlakuannya sebagai berikut.

\begin{tabular}{c|cccc}
\hline $\begin{array}{c}\text { Rerlakuan } \\
\text { Ulangan }\end{array}$ & \multicolumn{4}{|c}{ Ekstrak Bawang Putih (\%) } \\
\cline { 2 - 5 } & $\mathrm{P}_{0}$ & $\mathrm{P}_{1}$ & $\mathrm{P}_{2}$ & $\mathrm{P}_{3}$ \\
\hline 1 & $1 \mathrm{P}_{0}$ & $1 \mathrm{P}_{1}$ & $1 \mathrm{P}_{2}$ & $1 \mathrm{P}_{3}$ \\
2 & $2 \mathrm{P}_{0}$ & $2 \mathrm{P}_{1}$ & $2 \mathrm{P}_{2}$ & $2 \mathrm{P}_{3}$ \\
3 & $3 \mathrm{P}_{0}$ & $3 \mathrm{P}_{1}$ & $3 \mathrm{P}_{2}$ & $3 \mathrm{P}_{3}$ \\
4 & $4 \mathrm{P}_{0}$ & $4 \mathrm{P}_{1}$ & $4 \mathrm{P}_{2}$ & $4 \mathrm{P}_{3}$ \\
5 & $5 \mathrm{P}_{0}$ & $5 \mathrm{P}_{1}$ & $5 \mathrm{P}_{2}$ & $5 \mathrm{P}_{3}$ \\
\hline
\end{tabular}

\section{Prosedur Pengujian di Laboratorium}

Panelis :

1. Ibu rumah tangga Desa Baet Kajhu Aceh Besar sebanyak 10 orang

2. Dosen Jurusan Peternakan sebanyak 5 orang

3. Mahasiswa Jurusan Peternakan sebanyak 10 orang 


\section{Prameter Penelitian}

Parameter yang diamati skor organoleptik sie balu dalam penelitian terdiri dari:

a. penampilan umum (general appearance); data didapat dari penilaian panelis dengan cara melihat penampilan secara keseluruhan dari daging ayam sampel, lalu mengisi skor ke dalam kuesioner.

b. Warna (colour): data didapat dari penilaian para panelis dengan cara melihat warna dari daging kerbau, lalu mengisi skor kedalam kuesioner.

c. Aroma (odor): data didapat dari penilaian para panelis dengan cara mencium aroma dari daging sie balu, lalu mengisi skor kedalam kuesioner.

d. Rasa (taste): data didapat dari penilaian para panelis dengan cara merasa sie balu dan mengisi skor kedalam kuesioner. Penilaian rasa hannya dilakukan pada sie balu yang sudah di masak.

e. Keempukan: data didapat dari penilaian para panelis pada saat proses pengunyahan sie balu dan mengisi kuesioner. Penilaian keempukan hannya dilakukan pada sie balu yang sudah dimasak.

\section{HASIL DAN PEMBAHASAN}

\section{Uji Organoleptik}

Nilai uji organoleptik Sie Balu daging Kerbau dengan berbagai pemberian persentase bawang putih (Allium sativum) diperoleh dengan melihat respon dari panelis. Uji organoleptik tersebut meliputi warna, aroma, rasa dan keempukan. Hasil rataan organoleptik dari 25 orang panelis selengkapnya dapat dilihat pada Tabel 3.

Tabel 1. Rataan Nilai Organoleptik Sie Balu Daging Kerbau

\begin{tabular}{ccccc}
\hline \multirow{2}{*}{ Perlakuan } & \multicolumn{5}{c}{ Kriteria } \\
\cline { 2 - 5 } & Warna & Aroma & Rasa & Keempukan \\
\hline A & 3.7 & 3.65 & 3.9 & 3.9 \\
B & 3.4 & 3.75 & 3.45 & 3.65 \\
C & 3.55 & 3.55 & 3.65 & 3.9 \\
D & 3 & 3.2 & 3.6 & 3.3 \\
\hline
\end{tabular}

Tabel 1 menunjukkan bahwa nilai uji organoleptik Sie Balu daging Kerbau dengan rataan berkisar 3 - 3.9 (suka / sangat suka), warna 3 - 3.7 (suka / sangat suka), aroma 3.2 3.75 (suka / sangat suka), rasa 3.45 - 3.9 (suka / sangat suka), keempukan 3.3 - 3.9 (suka / sangat suka).

Rataan nilai organoleptik di atas menunjukkan bahwa semua kriteria mempunyai nilai yang sedikit berbeda (suka / sangat suka). Hasil analisis sidik ragam pada Sie Balu daging Kerbau dengan pemberian persentase bawang putih (Allium sativum) menunjukkan tidak adanya pengaruh nyata $(\mathrm{P}>0.05)$ terhadap uji warna, aroma, rasa dan keempukan.

\section{Uji Organoleptik Warna}

Hasil uji organoleptik terhadap warna Sie Balu daging Kerbau dengan berbagai pemberian persentase bawang putih (Allium sativum) dapat dilihat pada Tabel 2. 
Tabel 2. Persentase Uji Organoleptik Terhadap Warna Sie Balu Daging Kerbau

\begin{tabular}{ccc}
\hline Perlakuan & Rataan & Persentase \\
\hline A & 3.70 & 27.10 \\
B & 3.40 & 24.91 \\
C & 3.55 & 26.01 \\
D & 3.00 & 21.98 \\
\hline Total & 13.65 & 100.00 \\
\hline
\end{tabular}

Hasil sidik ragam warna Sie Balu daging Kerbau dengan berbagai pemberian persentase bawang putih (Allium sativum) menunjukkan pengaruh tidak berbeda nyata ( $\mathrm{P}>0.05)$, Panelis suka / sangat suka dengan rataan berkisar 3-3.7 atau dengan persentase $21.99 \%-27.1 \%$.

Panelis menilai sangat suka terhadap warna perlakuan A dan C, Tapi panelis menilai suka pada perlakuan B dan D. Panelis lebih cenderung menilai baik untuk warna Sie Balu pada setiap perlakuan, karena jenis daging, cara memasak dan pemberian bumbu - bumbu itu sendiri merupakan faktor yang mempengaruhi aroma. Salah satu penyebab perubahan warna daging yang diolah dan dimasak menurut Adawyah (2006) adalah reaksi antara asam amino dengan gula pereduksi serta antara asam - asam amino dengan gula pereduksi.

\section{Uji Organoleptik Aroma}

Hasil uji organoleptik terhadap aroma Sie Balu daging Kerbau dengan berbagai pemberian persentase bawang putih (Allium sativum) dapat dilihat pada Tabel 3.

Tabel 3. Persentase Uji Organoleptik Terhadap Aroma Sie Balu Daging Kerbau

\begin{tabular}{ccc}
\hline Perlakuan & Rataan & Persentase \\
\hline A & 3.65 & 25.79 \\
B & 3.75 & 26.50 \\
C & 3.55 & 25.10 \\
D & 3.20 & 22.61 \\
\hline Total & 14.15 & 100.00 \\
\hline
\end{tabular}

Hasil sidik ragam aroma Sie Balu daging Kerbau dengan berbagai pemberian persentase bawang putih (Allium sativum) menunjukkan pengaruh yang tidak berbeda nyata $(\mathrm{P}>0.05)$, panelis menilai suka / sangat suka dengan rataan berkisar 3.2 - 3.75 atau dengan persentase $22.61 \%-26.5 \%$.

Panelis menilai sangat suka terhadap aroma perlakuan A, B dan C, Tapi panelis menilai suka pada perlakuan D. Hal ini menunjukkan pemberian persentase bawang putih (Allium sativum) pada Sie Balu daging Kerbau dapat berpengaruh terhadap Aroma yang di hasilkan ketika setelah pembakaran Aroma sendiri juga merupakan salah satu hal yang dapat menarik perhatian konsumen, aroma yang enak kemungkinan besar memiliki rasa yang enak pula sehingga konsumen lebih cenderung menyukai makanan dari aromanya (Winarno, 1995).

\section{Uji Organoleptik Rasa}

Hasil uji organoleptik terhadap Rasa Sie Balu daging Kerbau dengan berbagai pemberian persentase bawang putih (Allium sativum) dapat dilihat pada Tabel 4. 
Tabel 4. Persentase Uji Organoleptik Terhadap Rasa Sie Balu Daging Kerbau

\begin{tabular}{ccc}
\hline Perlakuan & Rataan & Persentase \\
\hline A & 3.90 & 26.71 \\
B & 3.45 & 23.63 \\
C & 3.65 & 25.00 \\
D & 3.60 & 24.66 \\
\hline Total & 14.6 & 100.00 \\
\hline
\end{tabular}

Hasil sidik ragam rasa Sie Balu daging Kerbau dengan berbagai pemberian persentase bawang putih (Allium sativum) menunjukkan pengaruh yang tidak berbeda nyata $(\mathrm{P}>0.05)$, panelis menilai suka / sangat suka dengan rataan berkisar 3.45 - 3.9 atau dengan persentase $23.63 \%-26.71 \%$.

Panelis menilai sangat suka terhadap rasa perlakuan A, C dan D, tapi panelis menilai suka pada perlakuan B. Panelis lebih menyukai rasa Sie Balu daging Kerbau karena cara masak dan daging itu sendiri bukan karena pemberian persentase bawang putih (Allium sativum). Peramuan rasa itu sendiri merupakan suatu hal yang dapat membuat seseorang untuk dapat menentukan tingkat nilai kepuasan setelah menikmatinya. Lidah merupakan indra yang paling banyak terlibat dalam uji rasa, lidah bekerja untuk menilai suatu rasa dengan cara mengetahui kelarutan makanan tersebut dalam saliva dan kontak dengan syaraf perasa (Soekarto, 1985).

\section{Uji Organoleptik Keempukan}

Hasil uji organoleptik terhadap keempukan Sie Balu daging Kerbau dengan berbagai pemberian persentase bawang putih (Allium sativum) dapat dilihat pada Tabel 5.

Tabel 5. Persentase Uji Organoleptik Terhadap Keempukan Sie Balu daging Kerbau

\begin{tabular}{ccc}
\hline Perlakuan & Rataan & Persentase \\
\hline A & 3.90 & 26.44 \\
B & 3.65 & 24.75 \\
C & 3.90 & 26.44 \\
D & 3.30 & 22.37 \\
\hline Total & 14.75 & 100.00 \\
\hline
\end{tabular}

Hasil sidik ragam keempukan Sie Balu daging Kerbau dengan berbagai pemberian persentase bawang putih (Allium sativum) menunjukkan pengaruh yang tidak berbeda nyata $(\mathrm{P}>0.05)$, panelis menilai suka / sangat suka dengan rataan berkisar 3.3 - 3.9 atau dengan persentase $22.37-26.44 \%$.

Panelis menilai sangat suka terhadap keempukan perlakuan A, B dan C, Tapi panelis menilai suka pada perlakuan D. Sie Balu daging Kerbau sendiri sebenarnya memiliki daging yang alot dan keras. Menurut Soeparno (2005) keempukan maupun warna dari pada daging juga bisa di pengaruhi oleh umur ternak. semakin tua ternak, maka semakin menurunnya keempukan dari daging ternak tersebut. 


\section{Hasil Analisa Jumlah Mikroba}

Hasil analisa jumlah mikroba terhadap Sie Balu daging Kerbau dengan berbagai pemberian persentase bawang putih (Allium sativum) dapat dilihat pada Tabel 6.

Tabel 6. Jumlah Total Mikroba

\begin{tabular}{|c|c|c|}
\hline Pemberian & Perlakuan & TPC $\left(10^{6}\right)$ \\
\hline 200 gram Daging, 8 gram garam,0\% Bawang Putih & $1 \mathrm{P} 0$ & $8 \times 10^{6}$ \\
\hline 200 gram Daging, 8 gram garam,0\% Bawang Putih & $5 \mathrm{P0}$ & $4 \times 10^{6}$ \\
\hline 200 gram Daging, 8 gram garam, $10 \%$ Bawang Putih & 1P1 & $3 \times 10^{6}$ \\
\hline 200 gram Daging, 8 gram garam, $10 \%$ Bawang Putih & 5P1 & $3,5 \times 10^{6}$ \\
\hline 200 gram Daging,8 gram garam, $15 \%$ Bawang Putih & $1 \mathrm{P} 2$ & $8 \times 10^{6}$ \\
\hline 200 gram Daging,8 gram garam, $15 \%$ Bawang Putih & $5 \mathrm{P} 2$ & $1,5 \times 10^{6}$ \\
\hline 200 gram Daging, 8 gram garam, 20\% Bawang Putih & 1P3 & $1 \times 10^{6}$ \\
\hline 200 gram Daging,8 gram garam,20\% Bawang Putih & $5 \mathrm{P} 3$ & $1,5 \times 10^{6}$ \\
\hline
\end{tabular}

Berdasarkan Tabel 1 menunjukkan bahwa jumlah bakteri terbanyak pada Sie Balu daging kerbau dengan berbagai pemberian persentase bawang putih (Allium sativum) yang tidak diberi bawang putih (1P0) yaitu pada perlakuan 200 gram daging, 8 gram garam, $0 \%$ bawang putih sebesar $8 \times 10^{6} \mathrm{CFU} / \mathrm{g}$. Jumlah bakteri paling sedikit pada sie balu daging kerbau dengan berbagai pemberian persentase bawang putih (Allium sativum) di jumpai pada perlakuan (1P3) yaitu pada 200 gram daging, 8 gram garam, 20\% bawang putih yaitu sebesar $1 \times 10^{6} \mathrm{CFU} / \mathrm{g}$. Hal ini membuktikan bahwa dengan adanya pemberian bawang putih makan pertumbuhan mikroorganisme semakin berkurang. Kemampuan bawang putih sebagai antibakteri dalam menghambat pertumbuhan jumlah bakteri didukung oleh penelitian Lingga \& Rustama (2005) yang menyatakan bahwa ekstrak bawang putih yang dilarutkan dalam air bersifat antibakteri terhadap bakteri gram positif dan gram negatif, serta Wiryawan et al (2005) menyatakan bawang putih dapat menghambat pertumbuhan koloni bakteri pathogen.Terlihat bahwa semakin tinggi konsentrasi pada penelitian tersebut maka efektifitas dari bawang putih tersebut semakin terlihat. Pendapat ini sejalan dengan pernyataan Wiryawan (2005) yang menyatakan semakin tinggi konsentrasi ekstrak bawang putih maka aktivitas antibakterinya akan semakin tinggi.

\section{PENUTUP}

\section{Kesimpulan dan Saran}

Pemberian persentase bawang putih (Allium sativum) terhadap Sie Balu daging Kerbau ternyata tidak berpengaruh nyata $(\mathrm{P}>0.05)$ terhadap uji organoleptik warna, aroma, rasa dan keempukan dan saran Perlu dilakukan penelitian lebih lanjut tentang kadar lemak dan protein serta analisis kebusukan pada Sie Balu daging Kerbau setelah mengalami berbagai pemberian persentase bawang putih (Allium sativum).

\section{DAFTAR PUSTAKA}

Adawyah. (2006). Pengolahan dan Pengawetan . Jakarta: Bumi Aksara.

Lingga ME \& MM Rustama. 2005. Uji Aktivitas Antibakteri dari Ekstrak Air dan Etanol Bawang Putih (Allium sativum L.) terhadap Bakteri Gram Negatif dan Gram Positif 
yang Diisolasi dari Udang Dogol (Metapenaeus monoceros), Udang Lobster (Panulirus sp), dan Udang Rebon (Mysis dan Acetes). Jurnal Biotika 5 (2).

Soeparno. 2005. Ilmu dan Teknologi Daging. Gadjah Mada University Press, Yogyakarta. $131-136,165$

Soekarto S.T. 1985. Penilaian Organoleptik untuk Industri Pangan dan Hasil

Pertanian. Jakarta: Bhratara Karya Aksara

Widaningrum \& Winarti, C. 2005. Kajian Pemanfaatan Rempah-Rempah Sebagai Pengawet Alami pada Daging. Bogor, Institut Pertanian Bogor.

Winarno, F. G. 1995. Kimia Pangan dan Gizi. Gramedia: Jakarta

Wiryawan KG, S Suharti \& M Bintang. 2005. Kajian Antibakteri Temulawak, Jahe dan Bawang Putih terhadap Salmonella typhimurium serta Pengaruh Bawang Putih terhadap Performans dan Respons Imun Ayam Pedaging. Media Peternakan 28 (2):52-62. 